Sari Pediatri, Vol. 3, No. 3, Desember 2001: 141 - 146

\title{
Pneumonia Atipik pada Anak
}

\author{
Mardjanis Said
}

Di negara berkembang penyebab utama pneumonia pada balita ialah Streptococcus pneumoniae, Haemophillus influenzae dan Streptococcus aureus, yang responsif terhadap antibiotik golongan beta-laktam. Namun di samping itu ditemukan pula pneumonia yang tidak responsif terhadap antibiotik golongan beta-laktam, yang disebabkan oleh Mycoplasma pneumoniae, Chlamydia pneumoniae, Chlamydia trachomatis. Infeksi karena Chlamydia trachomatis sering terjadi melalui transmisi vertikal dari ibu pada masa persalinan. Chlamydia pneumoniae kronik diduga berhubungan dengan terjadinya eksaserbasi asma pada anak, pneumonia atipik yang umumnya responsif terhadap antibiotik makrolid. Peningkatan kewaspadaan terhadap adanya pneumonia atipik, berkembangnya deteksi yang lebih akurat serta pengobatan yang efektif dengan antibiotik makrolid yang lebih tepat diharapkan akan menurunkan morbiditas penyakit.

Kata kunci: pneumonia atipik, Mycoplasma pneumoniae, Chlamydia pneumoniae, Chlamydia trachomatis, makrolid.

$p$

neumonia merupakan infeksi saluran napas akut yang paling sering menyebabkan kematian pada anak di negara berkembang. Umumnya penyebab pneumonia ialah bakteri tipik terutama Streptococcus pneumoniae, Haemophilus influenzae dan Staphylococcus aureus. Pneumonia bakteri ditandai oleh gejala respiratorik akut dan gambaran foto rontgen infiltrat bercak-bercak atau infiltrat difus yang dikenal sebagai gambaran bronkopneumonia atau pneumonia lobaris. Pneumonia bakteri umumnya responsif terhadap pengobatan dengan antibiotik golongan beta-laktam. Di samping itu ditemukan pneumonia yang tidak responsif terhadap antibiotik beta-laktam, pneumonia ini digolongkan sebagai pneumonia atipik (atypical pneumonia). Beberapa bakteri atipik respiratorik yang telah dikenal ialah Mycoplasma pneumoniae, Chlamydia pneumoniae, Legionella pneumophila dan Ureaplasma urealyticum. Mycoplasma pneumoniae dan Chlamydia spp. merupakan penyebab

\footnotetext{
Alamat korespondensi:

Dr. Mardjanis Said, Sp.A(K),

Subbagian Pulmonologi. Bagian Ilmu Kesehatan Anak FKUI-RSCM, Jl. Salemba 6, Jakarta 10430.

Telepon 021-3916043/3148930, Fax. 021-3148931.
}

potensial infeksi saluran napas dan pneumonia pada anak, sedangkan Legionella pneumophila dan Ureaplasma urealyticum jarang dilaporkan sebagai penyebab infeksi pada anak. Chlamydia trachomatis sering ditemukan sebagai penyebab infeksi akut respiratorik pada bayi melalui transmisi vertikal dari ibu pada masa persalinan. Makalah ini akan membahas peranan Mycoplasma pneumoniae dan Chlamydia spp. sebagai penyebab pneumonia atipik pada anak yang patut dipertimbangkan.

\section{Penyebab Pneumonia Atipik}

Penyebab tersering pneumonia atipik pada anak ialah M. pneumoniae dan C. pneumoniae, yang diperkirakan prevalensinya mencapai $40 \%$ kasus. Deteksi kedua mikroorganisme ini sukar dilakukan sehingga pada masa lalu data prevalensi tidak dapat dipastikan. Dengan berkembangnya metode deteksi seperti microimmunofluorescence (MIF) dan polymerase chain reaction (PCR) yang lebih unggul dari kultur maka akhir-akhir ini banyak laporan tentang prevalensi yang dapat dipercaya.

Diduga pneumonia mikoplasma mencapai 30- 
50\% dan pneumonia klamidia 10-20\% kasus di antara penyebab pneumonia atipik. Pola infeksi bervariasi di setiap negara. Di Nigeria dilaporkan $31 \%$ anak dengan infeksi $M$. pneumoniae prevalensi tertinggi adalah umur 6-10 tahun sedangkan suatu studi di Jepang menunjukkan dari $22 \%$ pneumonia yang disebabkan $M$. pneumoniae prevalensi tertinggi ialah umur 4 tahun. Infeksi $M$. pneumoniae bersifat endemik namun epidemik dapat terjadi dengan interval 4-7 tahun. ${ }^{1}$ Wirjodiardjo M, dkk (1988) melaporkan 41\% kasus seropositif terhadap $M$. pneumoniae pada anak dengan infeksi saluran napas akut dan batuk kronik berulang di Bagian Ilmu Kesehatan Anak FKUI Jakarta. ${ }^{2}$

Prevalensi seropositif C.pneumoniae tergantung golongan umur. Studi mengenai antibodi menunjukkan seropositif pada masa bayi sangat rendah namun meningkat dengan konsisten sampai masa dewasa, maka lebih dari $50 \%$ orang dewasa telah mempunyai antibodi terhadap C. pneumoniae (Gambar 1).

Bahkan dilaporkan pada populasi karyawan kesehatan seropositif terhadap C. pneumoniae telah mencapai lebih dari $80 \%$. Hal ini menunjukkan bahwa infeksi respiratorik asimptomatik dapat terjadi dan dapat menetap berbulan-bulan. Pneumonia klamidia dapat ditemukan di seluruh dunia tetapi lebih sering di daerah tropis, bersifat endemik namun epidemik dapat terjadi dengan interval 3-4 tahun. Umumnya perjalanan penyakit dan gejala klinik pneumonia klamidia sukar dibedakan dengan pneumonia mikoplasma.

\section{Prosentase}

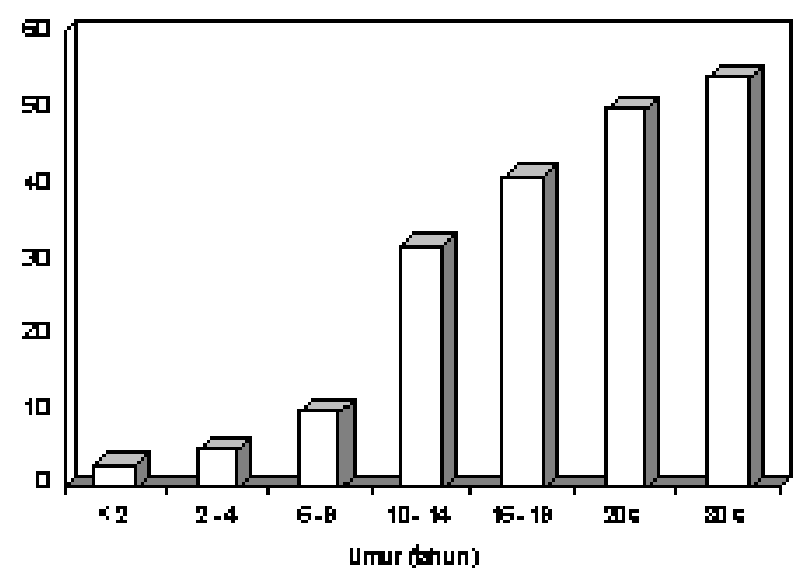

Gambar 1. Prevalensi infeksi C. pneumoniae menurut golongan umur. ${ }^{3}$

Dikutip dari Grayston dkk., 1990

\section{Spesies Mycoplasma}

Mikoplasma dan ureaplasma merupakan mikroorganisme hidup bebas paling kecil termasuk famili Mycoplasmataceae, ordo Mycoplasmatales dan kelas Mollicutes. Kelas Mollicutes terdiri dari 2 genus a) genus Mycoplasma, yang tidak menghidrolisis urea dan b) genus Ureaplasma, yang dapat menhidrolisis urea. Mikroorganisme yang termasuk kedua genus ini tidak mempunyai dinding sel sehingga cenderung merupakan spesies yang paling sering menyebabkan infeksi respiratorik pada manusia. M pneumoniae ialah mikroorganisme Gram negatif, tidak mempunyai dinding sel, terdiri dari membran sel dan sitoplasma. Bentuknya polimorf mulai dari bulat sampai bentuk filamen dengan ukuran elementary body berkisar antara $105-120 \mathrm{~nm}$ sedangkan sel yang matur berkisar antara 690-750 nm.

\section{Spesies Chlamydia}

Klamidia ialah mikroorganisme yang mempunyai siklus hidup bifasik : a) sebagai elementary body (EB) berukuran lebih kecil (300-400 nm), ekstraselular, infeksius dan b) sebagai reticulate body (RB) berukuran lebih besar (800-1000 nm), intraselular, tidak infeksius, mempunyai aktivitas metabolik aktif dan mempunyai daya untuk membelah diri hingga disebut juga reproductive form. Di samping itu ada bentuk-antara yang disebut intermediate body (IB) yang merupakan suatu kondensasi DNA (condensing form). Klamidia ialah mikroorganisme Gram negatif, non-motile, nonciliated dan mempunyai permukaan sel yang sanggup menarik nutrien dari sitoplasma pejamu. In vivo klamidia yang berbentuk EB menempel pada mikrovili sel pejamu dan secara aktif penetrasi ke dalam sel. Di dalam sel pejamu klamidia berubah bentuk menjadi bentuk RB yang mampu mensintesis DNA, RNA dan protein sel pejamu namun tidak mampu memproduksi ATP, oleh karena itu klamidia selalu tergantung kepada sel pejamu untuk mendapatkan ATP, hingga klamidia disebut juga energy parasite. Di dalam sel pejamu klamidia akan membelah diri dan dalam waktu 92 jam setelah infeksi sel pejamu akan mengeluarkan lagi klamidia dalam bentuk EB yang akan mencari sel pejamu berikutnya. Klamidia terdiri dari 3 spesies yang dapat menimbulkan kelainan pada manusia yaitu C.trachomatis, C.psitacci dan C.pneumoniae. Perbedaan karakteristik ke tiga spesies itu terlihat pada Tabel 1. 
Sari Pediatri, Vol. 3, No. 3, Desember 2001

Tabel 1. Karakteristik spesies Chlamydid ${ }^{4}$

\begin{tabular}{llll}
\hline C.trachomatis & C.psitacci & C.pneumoniae & \\
\hline Pejamu & manusia & $\begin{array}{l}\text { burung,manusia, } \\
\text { mamalia }\end{array}$ & manusia \\
\hline Jumlah serovarian & 15 & 4 & 1 \\
Morfologi EB & bulat & bulat & pervariasi, padat \\
Morfologi RB & bulat, vacuolar & tidak & bulat, padat \\
Glikogen & ada & tidak & tidak \\
Peka terhdp sulfonamid & ya & $<10$ & tidak \\
Prosentase homologi DNA & $<5$ & ada & $94-100$ \\
Plasmid DNA & ada & peternak, Dr hewan & tidak \\
Populasi & bayi & aerosol: & semua umur \\
Transmisi & vertikal: & binatang-manusia & man-manusia \\
& Ibu-bayi & $150-200$ & 100000 \\
\hline Insiden pneumonia/thn & $10000-15000$ & & \\
\hline
\end{tabular}

Infeksi C. psitacci pada anak jarang ditemukan. Infeksi $C$. trachomatis dilaporkan sebagai infeksi vertikal dari ibu kepada bayi di masa persalinan, jarang ditemukan pada masa anak namun infeksi $C$ pneumoniae dapat mengenai semua usia.

\section{Infeksi Respiratorik M.pneumoniae}

Infeksi mikoplasma mulai secara bertahap dengan gejala demam dan nyeri kepala. Batuk mulai 3-5 hari setelah awal penyakit, mula-mula tidak produktif kemudian menjadi produktif. Sputum mungkin berbercak darah, batuk dapat menetap sampai berminggu-minggu. Auskultasi bervariasi dan mengi tercatat ditemukan pada $40 \%$ kasus. Gambaran radiologik bervariasi misalnya infiltrat intersisial, retikuler, retikulonodular, bercak konsolidasi, pembesaran kelenjar hilus, kadang-kadang disertai efusi pleura. Infeksi M.pneumoniae sering tidak terdiagnosis karena pemeriksaan mikrobiologik tidak dapat dipakai sebagai alat diagnostik, maka tidak dikerjakan secara rutin. Biakan memerlukan waktu 2 minggu dan uji serologik hanya berguna bila telah terjadi pembentukan antibodi, pada saat itu penyakit telah sangat berkembang. Umumnya gejala klinik infeksi $M$. pneumoniae ringan dan kadang-kadang dapat sembuh spontan, namun kasus berat dan mengancam jiwa juga dapat terjadi.

Oermann C dkk (1997) melaporkan seorang anak umur 5 tahun dengan severe necrotizing pneumonitis disebabkan M.pneumoniae. Kasus ini mula-mula diobati sebagai faringitis yang tidak responsif dengan amoksisilin. Pada perjalanan penyakit timbul distres pernapasan yang tidak responsif juga dengan seftriakson intra muskular. Gambaran foto dada AP menunjukkan perpadatan lobus kanan tengah dan bawah serta efusi pleura (Gambar 2), pada CT-scan dengan kontras didapatkan gambaran homogen masif lobus kanan, tengah dan bawah; tidak terlihat aerasi dan vascular marking (Gambar 3). Diagnosis M.pneumoniae ditegakkan dengan pemeriksaan serologik dan PCR. Dilakukan lobektomi dan terapi dengan eritromisin, anak dipulangkan dalam keadaan baik setelah 17 hari perawatan. ${ }^{5}$

\section{Infeksi Respiratorik C. trachomatis pada bayi}

Umumnya bayi mendapat infeksi C.trachomatis dari ibu pada masa persalinan. Infeksi dapat berupa konjungtivitis dan infeksi saluran napas. Infeksi saluran napas kebanyakan berupa infeksi nasofaring yang umumnya asimptomatik. Hanya sekitar $30 \%$ bayi yang terinfeksi dengan C. trachomatis yang menjadi pneumonia. Umumnya gejala baru timbul sekitar umur 4-12 minggu, beberapa kasus dilaporkan terjadi pada usia 2 minggu namun jarang terjadi setelah umur 4 bulan. Gejala utama ialah batuk tanpa demam, bayi kelihatan takipne kadang-kadang terdengar ronki atau mengi. Gambaran radiologik tidak khas, umumnya 


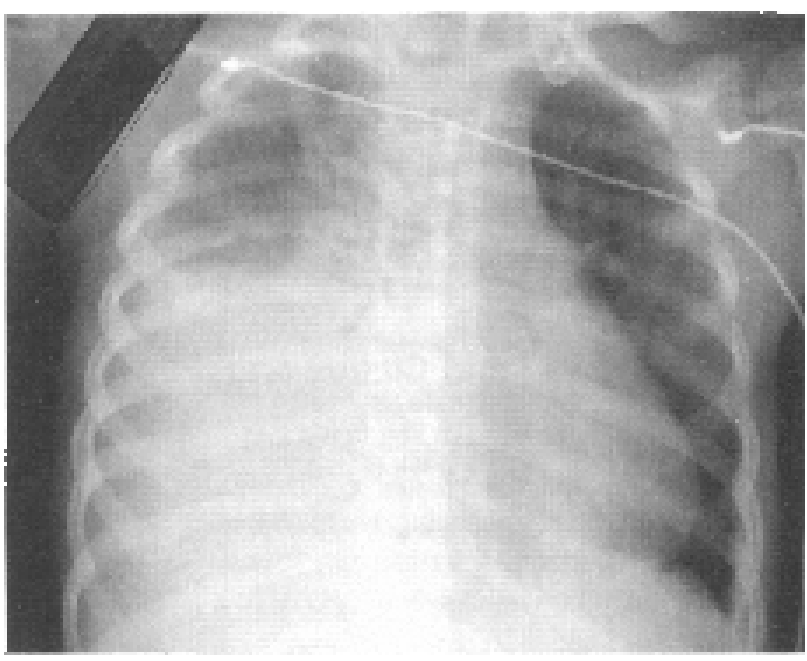

Gambar 2. Foto dada AP menunjukkan perpadatan lobus kanan tengah dan bawah serta efusi pleura

terlihat tanda-tanda hiperinflasi. Radskowski dkk (1981) melaporkan dari 125 kasus pneumonia klamidia pada bayi menunjukkan gambaran hiperinflasi bilateral dengan berbagai bentuk infiltrat difus meliputi infiltrat intersisial, retikulonodular, atelektasis dan bronkopneumonia. Tidak ditemukan konsolidasi lobaris dan efusi pleura. ${ }^{6}$ Van den Borre $\mathrm{dkk}^{7}$ melaporkan satu kasus pneumonia yang disebabkan infeksi $C$. trachomatis pada neonatus yang ditemukan secara tidak sengaja pada pemeriksaan radiologik dada pra operasi elektif hernia inguinalis. Ditemukan gambaran radiologis infiltrat noduler intersisial difus

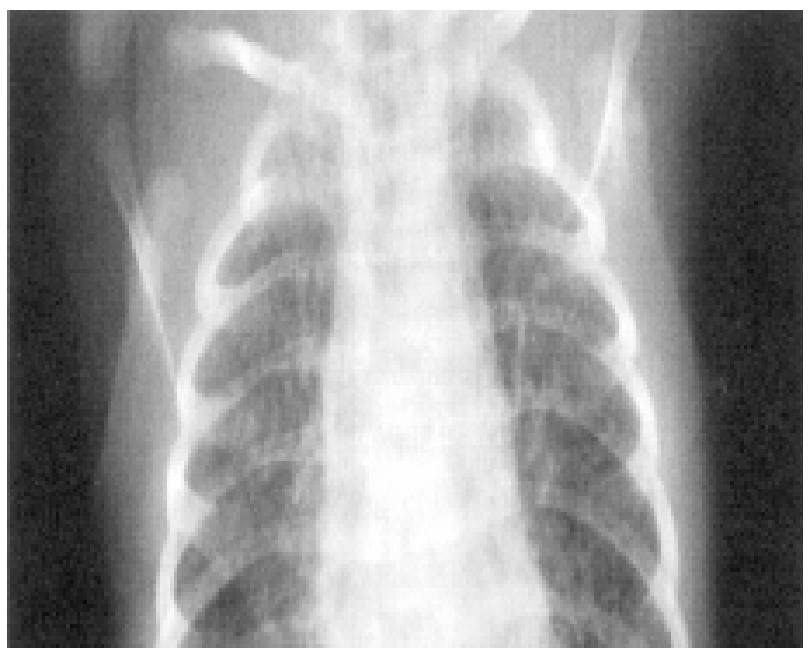

Gambar 4. Foto dada AP menunjukkan gambaran milier pada kedua lapangan paru

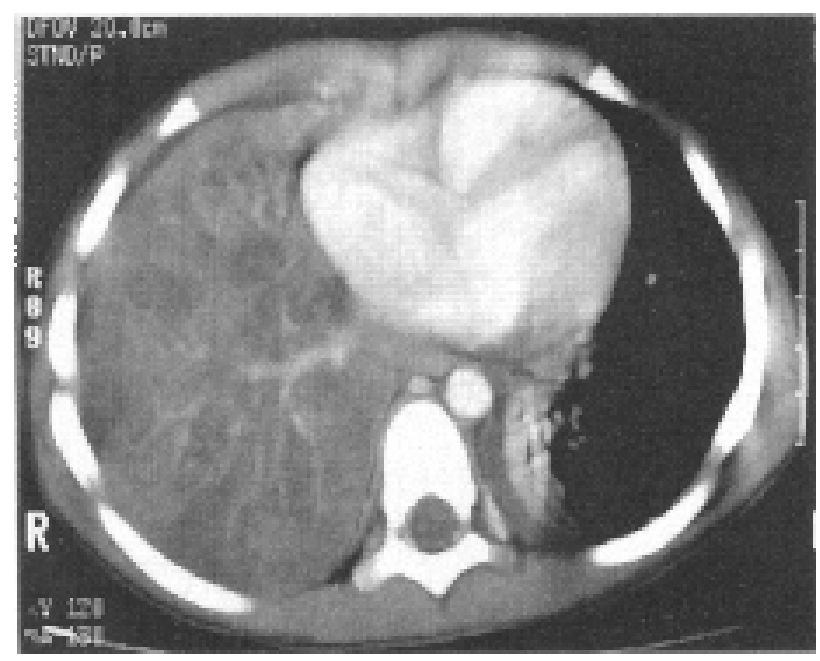

Gambar 3. Pada CT-scan dengan kontras didapatkan gambaran homogen masif lobus kanan, tengah dan bawah, tidak terlihat aerasi dan vascular marking.

bilateral menyerupai gambaran tuberkulosis milier (Gambar 4 dan 5). Dengan pengobatan eritromisin $50 \mathrm{mg} / \mathrm{kgBB} /$ hari, gejala menghilang dalam 2 minggu.

\section{Infeksi Respiratorik C. pneumoniae}

C.pneumoniae merupakan penyebab tersering infeksi saluran napas akut atas seperti faringitis, sinusitis dan

GAMBAR ASLINYA KURANG BAGUS. LAGI DIPERBAIKI

Gambar 5. Foto dada lateral memperlihatkan gambaran milier dan diafragma rendah karena hiperinflasi paru 
otitis. Namun juga dapat menyebabkan infeksi saluran napas akut bawah seperti pneumonia, bronkitis dan eksaserbasi akut chronic obstructive pulmonary disease (COPD) pada orang dewasa. C.pneumoniae juga dihubungkan dengan penyakit kronik lain seperti endokarditis, artritis, sindrom Gullian Barre dan eritema nodosum. Gejala klinik mula-mula ditandai dengan gejala seperti flu yaitu batuk kering, mialgia, nyeri kepala, maleise umum, pilek dan demam tidak tinggi, pada pemeriksaan dada sering tidak jelas. Gejala respiratorik umumnya tidak mencolok. Sering ditemukan leukosit darah tepi normal. Gambaran radiologik dada menunjukkan infiltrat difus atau gambaran peribronkial non-fokal yang jauh lebih berat dibandingkan dengan gejala klinik.

\section{Hubungan antara Infeksi C.pneumoniae Kronik dengan Asma}

Telah diketahui bahwa infeksi virus adalah penyebab penting eksaserbasi asma, studi terbaru menunjukkan bahwa infeksi $C$ pneumoniae juga berperan dalam patogenesis asma. Cunningham dkk (1998) dan Johnston SL (1999) melaporkan adanya hubungan antara infeksi C.pneumoniae kronik dengan eksaserbasi asma pada anak. Mereka mendapatkan prevalensi tinggi terhadap infeksi kronik dengan C.pneumoniae pada anak dengan asma. ${ }^{8,9}$ Akhir-akhir ini juga dilaporkan adanya hubungan antara infeksi C.pneumoniae dengan timbulnya penyakit arteri koroner. Namun, walaupun terdapat hubungan kausal yang langsung tetapi patogenesis pasti belum jelas.

\section{Pengobatan}

M.pneumoniae dan C.pneumoniae tidak responsif terhadap antibiotik golongan beta-laktam; oleh karena M.pneumoniae tidak mempunyai dinding sel dan C.pneumoniae merupakan bakteri intrasel. Studi menunjukkan adanya efikasi klinis tetrasiklin (4x250mg sehari selama 10 hari) dan eritromisin (4x $1 \mathrm{~g}$ sehari selama 10 hari) pada infeksi respiratorik oleh M.pneumoniae, namun tidak efektif mengeradikasi mikroorganisme dari jaringan. Makrolid yang lebih baru seperti klaritromisin menunjukkan efektivitas klinik yang baik dan mampu mengeradikasi mikroorganisme ini. Umumnya makrolid baru ini mempunyai daya penetrasi ke dalam sel yang lebih baik, konsentrasi dalam jaringan dan sekret yang lebih tinggi, konsentrasi hambat minimum (KHM) lebih rendah dan waktu-paruh lebih panjang. Di samping makrolid mempunyai spektrum antibakteri yang lebih luas juga mencakup bakteri tipik dan atipik. (Tabel 2)

Chia Yin Chong dkk (1997) melaporkan terdapatnya perubahan pola spektrum etiologi infeksi saluran napas akut dari periode tahun 1988 ke tahun 1995, persentase penyebab M.pneumoniae turun dari $33 \%$ menjadi 7\% (Tabel 3). Mereka menduga penurunan persentase tersebut berhubungan dengan peningkatan kewaspadaan para klinisi terhadap infeksi M.pneumoniae dan kecenderungan pemakaian makrolid sejak tahun $1988 .^{10}$

\section{Kesimpulan}

M. pneumoniae dan C. pneumoniae merupakan penyebab penting pneumonia atipik pada anak. Walaupun gejala klinik umumnya ringan namun dapat

Tabel 2. Aktivitas in-vitro Azitromisin, Klaritromisin dan Eritromisin Terhadap M. pneumoniae dan C.pneumoniae ${ }^{l}$

\begin{tabular}{lll}
\hline & \multicolumn{2}{l}{$\begin{array}{l}\text { Konsentrasi Hambat Minimum } \\
\text { Obat }\end{array}$} \\
\cline { 2 - 3 } & M. pneumoniae $(\mathrm{mg} / \mathrm{L})$ & \\
\hline Azitromisin & $\leq 0.001-0.015$ & $0.063-0.250$ \\
Klaritromisin & $\leq 0.004-0.125$ & $0.004-0.030$ \\
Eritromisin & $\leq 0.004-0.063$ & $0.063-0.250$ \\
Tetrasiklin & $0.100-0.500$ & $0.063-0.250$ \\
Ofloksasin & $0.050-2.000$ & $0.250-4.000$ \\
Sulfametoksazol & Tidak ada data & $<500$ \\
\hline
\end{tabular}

Sumber: Dikutip dari Pechere JC, 1995

Tabel 3. Etiologi Infeksi Saluran Napas Akut pada Anak di Singapura tahun 1988-1995

\begin{tabular}{lcc}
\hline & $1995(\mathrm{n}=397)$ & $1988(\mathrm{n}=240)$ \\
\cline { 2 - 3 } Etiologi & $\mathrm{n}(\%)$ & $\mathrm{n}(\%)$ \\
\hline Virus & $164(41.3)$ & $66(27.5)$ \\
M.pneumoniae & $28(7)$ & $80(33)$ \\
Bakteri & $118(29.7)$ & $35(15)$ \\
\hline
\end{tabular}


terjadi kasus berat yang fatal dan mengancam jiwa. Pengobatan dengan makrolid terutama makrolid yang lebih baru kelihatannya mempunyai efektivitas klinik dan eradikasi yang baik. Peningkatan kewaspadaan terhadap $M$. pneumoniae dan C. pneumoniae sebagai penyebab potensial pneumonia atipik pada anak, disertai dengan perkembangan metode deteksi yang lebih akurat diharapkan akan menurunkan morbiditas penyakit.

\section{Daftar Pustaka}

1. Pechere JC. Atypical pneumonia. Dalam: Pechere JC, penyunting, Community-acquired pneumonia in children, edisi ke-1, London, Cambridge Medical Publication, 1995.h.55-61.

2. Wirjodiardjo M, Sigarlaki JM, Said M, Boediman I, Rahajoe NN, Rahajoe N. Mycoplasma pneumoniae sebagai penyebab infeksi saluran napas akut (ISNA) pada anak. MKI, 1988; 38:516-24.

3. Grayston dkk,. Population prevalence of Chlamydia pneumoniae microimmuno- fluorescence immunoglobin
G antibody. J Infect Dis 1990; dikutip dari Pechere JC.

4. Chirgwin K, Hammerschlag MR. Chlamydia pneumoniae. Dalam: Eigen RD, Cherry JD, penyunting, Textbook of Pediatric Infectious Diseases, edisi ke-13, Philadelphia, London, Tokyo, WB Saunders Company, 1992.h.266.

5. Oermann C, Sockrider MM, Langston C. Severe necrotizing pneumonitis in a child with mycoplasma pneumoniae infection. Pediat Pulmonol 1997; 24:61-5.

6. Radkowski dkk,. Chlamydia pneumoniae in infants: Radiography in 125 cases. AJR 1981; dikutip dari Van den Borre C, Dab I, Malfroot A, Naessens A.

7. Van den Borre C, Dab I, Malfroot A, Naessens A. Subclinical infantile chlamydia trachomatis pulmonary infection. Pediat Pulmonol 1993; 15:263-5.

8. Cunningham AF, Johnston SL, Julious SA, Lampe FC, Ward ME. Chronic chlamydia pneumoniae infection and asthma exacerbations in children. Eur Respir J 1998; 11:345-9.

9. Johnston SL. The role of viral and atypical bacterial pathogens in asthma pathogenesis. Pediat Pulmonol 1999; Suppl 18:141-3.

10. Chong C-Y, Lim W-H, Heng J-T, Chay O-M. The changing trend in the pattern of infective etiologies in childhood acute lower respiratory infection. Acta Paed Japonica 1997; 39:317-21. 